\title{
Dziedzictwo wielokulturowości jako podstawa zrównoważonego rozwoju turystyki miejskiej w Warszawie - czas pandemii COVID-19
}

\author{
Anna Ostrowska-Tryzno \\ Anna Pawlikowska-Piechotka
}

STRESZCZENIE

Wprowadzenie: znaczenie wielokulturowości dla rozwoju turystyki, podkreślane konsekwentnie w literaturze przedmiotu, świadczy o popularności tej formy turystyki. Polska historycznie była krajem przejściowym między Wschodem a Zachodem, krajem, w którym obok siebie istniały różne kultury: polska, niemiecka, żydowska i rosyjska. Polska przez wieki była miejscem spotkań różnych religii i kultur, a dzisiejszy krajobraz wciąż na to wskazuje. Katastrofa II wojny światowej przyniosła unicestwienie społeczeństwa wielokulturowego i stworzyła niespotykaną dotąd w naszej historii jednorodność.

Dziedzictwo żydowskie i miejska turystyka kulturowa: w swojej prawie 2000-letniej diasporze Żydzi byli obecni w Polsce od ośmiuset lat: od wczesnego średniowiecza do Holokaustu, do Zagłady w okresie II wojny światowej. Od innych grup społecznych Żydów wyróżniała religia, język, zwyczaje, sztuka i architektura. W okresie międzywojennym XX w. Polska była domem największej społeczności żydowskiej w Europie, wyróżniającej się ogromną żywotnością kulturową i intelektualną. Zachowane ślady, materialne i niematerialne wielokulturowości w Warszawie stały się podstawą rozwoju turystyki kulturowej. Czas pandemii a turystyka miejska: wybuch pandemii COVID-19 silnie uderzył w sektor turystyczny: obowiązują ograniczenia w podróżowaniu i zwiedzaniu obiektów. Dlatego konieczna jest weryfikacja prognoz i przygotowanie nowych rekomendacji dla kierunków turystyki kulturowej w czasie pandemii i w okresie po jej zakończeniu.

Podsumowanie i wnioski: zainteresowanie dziedzictwem żydowskim jest silne od kilku dekad i wielu turystów, zarówno krajowych, jak i zagranicznych chce zgłębiać kulturę żydowską i zabytki przeszłości. Pomimo ograniczeń sanitarnych nawet w czasie pandemii jest to możliwe, jednak potrzebne jest wypracowanie racjonalnych procedur, aby zarówno zapewnić reżim sanitarny, jak i odbudować zaufanie konsumentów.

Słowa kluczowe: wielokulturowość, turystyka miejska, dziedzictwo kulturowe Żydów, pandemia COVID-19 


\section{Wprowadzenie}

Turystyka miejska, z uwagi na swoją złożoność, jest zagadnieniem wielorakim, trudnym do jednoznacznego zdefiniowania. W uproszczeniu - są to różnorodne formy aktywności w przestrzeni miasta, np. krajoznawstwo, uczestnictwo w imprezach kulturalnych i sportowych, zwiedzanie muzeów, udział w konferencjach i wystawach, pobyty służbowe i wycieczki szkolne. Ponieważ trudno jest porównywać ruch turystyczny w miastach małych jak np. Lanckorona, Kazimierz Dolny nad Wisłą i ośrodkach wielkich jak Warszawa, Kraków, Wrocław, Trójmiasto - coraz częściej badacze operują węższymi pojęciami, precyzując, czy badane zjawisko jest typowe dla ośrodków małych czy wielkich.

Turystyka miejska nie jest zjawiskiem nowym, jej tradycje w Europie siegaja cywilizacji antycznych, ale w wiekach XX i XXI stała się zjawiskiem powszechnym. W konsekwencji władze wielu miast w Europie i w Polsce biora pod uwage strategie rozwoju turystyki rozważając kierunki rozwoju społeczno-gospodarczego. Istotna pomocą dla polityki rozwoju miast są badania nad istotą i pożądanym modelem rozwoju turystyki miejskiej.

Ważne miejsce turystyki kulturowej w literaturze naukowej świadczy o długiej historii i bogatej tradycji tej formy turystyki. W ciagu wielu wieków cywilizacji europejskiej turystyka miejska znacznie się rozwinęła: od odwiedzania świętych miejsc, uzdrowisk w starożytnych cywilizacjach, pielgrzymek odbywanych w średniowiecznej Europie, turystyki miejskiej (Paryża, Rzymu, Florencji i Wenecji) cieszącej się popularnością podczas European Grand Tours (Wielkich Podróży), które były popularne wśród arystokracji i burżuazji w wiekach XVIII i XIX, odkrywanie uzdrowisk w XIX w., wystaw światowych i imprez sportowych na przełomie XIX i XX w. [Law 1996; Williams 2003]. Bogactwo tradycji, historii, kultury i różnorodności wielkomiejskiej są silną motywacją dla współczesnych podróżników. W czasach nam współczesnych turystyka miejska jest motywowana - w całości lub częściowo - zainteresowaniem historia, dziedzictwem kulturowym, materialnym i niematerialnym, codziennym stylem życia, ale także podróżami służbowymi, uczestniczeniem w negocjacjach handlowych, konferencjach i wystawach, festiwalami i imprezami sportowymi. W ostatnich dziesięcioleciach byliśmy w stanie obserwować dynamiczny rozwój różnych form turystyki miejskiej, stąd to pojęcie można interpretować na wiele sposobów [Dallen, Boyd 2003; EESC 2005a; EESC 2005b; Hall 2000; Inskeep 1991; Loyke, Edmunds 2007; Sigala, Leslie 2006; Smith 2006; UNWTO 2005]. Jednak, co do dominującego motywu turystów badacze są zgodni: główną motywacją odwiedzających wielkie ośrodki jest ciekawość miejsca, chęć poznania specyfiki wielkiego ośrodka, zainteresowanie innymi ludźmi, ich kulturą i obyczajem.

Miejska turystyka kulturowa, co było istotnym założeniem w naszym projekcie badawczym, może być rozumiana w szerokim tego słowa znaczeniu jako nie tylko „kultura wysoka" (zabytki architektury, muzea), ale także wartości niematerialne: tradycje religijne i obyczajowe, język, muzyka i jedzenie. Chociaż tradycyjne europejskie turystyczne destynacje miejskie, takie jak Rzym, Londyn, Amsterdam, Paryż, Wenecja, Ateny, Barcelona, Lizbona, Madryt i Wiedeń, wciąż są silnym magnesem dla turystów, pojawiają się nowsze kierunki, które przyciagają. Sa to głównie wschodnioeuropejskie wielkie miasta: Budapeszt, Praga, 
Wilno, Lwów, Kraków i Warszawa, uznawane od kilku dekad na arenie międzynarodowej za obiecujace miejsca rozwoju turystyki kulturowej [EESC 2005a; EESC 2005b; ECTN 2020; Smith 2006; Williams 200]. W 2019 r. w Warszawie doświadczyliśmy ponad $10 \mathrm{mln}$ wizyt turystycznych [GUS 2020], inspirowanych głównie podróżami służbowymi (turystyka biznesowa, konferencyjna, wystawiennicza), ale także zainteresowaniem i odwiedzaniem muzeów i galerii, uczestnictwem w festiwalach i pokazach kulturalnych. Prawie $30 \%$ osób w tej grupie stanowili turyści z zagranicy (Niemcy, Ukraina, Stany Zjednoczone i Włochy) [um. warszawa.pl 2021].

Silną inspiracją dla wielu turystów odwiedzających Warszawę była i jest wielokulturowa tradycja miejsca i jej zróżnicowane etnicznie dziedzictwo, materialne i niematerialne.

W ciagu ostatnich kilku lat znacząco wzrosła popularność muzeów, co potwierdzają dane statystyczne (tabela 1).

Tabela 1. Muzea o najwyższej frekwencji w 2019 r. w Warszawie

\begin{tabular}{|c|l|c|}
\hline Lp. & \multicolumn{1}{|c|}{ Muzeum } & Liczba odwiedzających \\
\hline 1. & Muzeum Łazienki Królewskie w Warszawie & 4966858 \\
\hline 2. & Muzeum Pałacu Króla Jana III Sobieskiego w Wilanowie & 3115797 \\
\hline 3. & Zamek Królewski w Warszawie - Muzeum & 1033098 \\
\hline 4. & Muzeum Narodowe w Warszawie & 633668 \\
\hline 5. & Muzeum Powstania Warszawskiego w Warszawie & 545356 \\
\hline 6. & Muzeum Historii Żydów Polskich POLIN w Warszawie & 486952 \\
\hline
\end{tabular}

Źródło: na podstawie danych statystycznych GUS - Kultura w 2019 r. [www.stat.gov.pl, 2021]

\section{Historia, tradycja i dziedzictwo żydowskie w Warszawie}

Polska historycznie była krajem przejściowym między Wschodem a Zachodem, krajem, gdzie obok siebie istniały różne kultury: polska, niemiecka, żydowska, rosyjska. Polska przez wieki była miejscem spotkań różnych religii i kultur, czego dowodem jest dzisiejszy krajobraz zachowany w historycznych miastach, zarówno w wielkich ośrodkach - Kraków, Warszawa, jak i mniejszych - Zamość, Tykocin, Kazimierz Dolny nad Wisłą. O tej różnorodności kulturowej świadczą zachowane zabytki architektury: cerkwie prawosławne i katolickie, kaplice kalwińskie i protestanckie, synagogi i meczety, które wznoszono na terenie Polski, dając świadectwo różnorodności kulturowej.

Katastrofa II wojny światowej w latach 1939-1945 przyniosła zagładę wielokulturowego społeczeństwa i stworzyła nieznaną w naszej historii jednorodność.

Tuż przed II wojną światową w Polsce mieszkało 3,5 mln Żydów, co stanowiło około 10\% całej populacji kraju. W okresie II Rzeczypospolitej Warszawa była największym w Europie skupiskiem ludności żydowskiej, której liczebność przekraczała 350 tys., stanowiąc prawie 
40\% mieszkańców miasta. Główne zamieszkiwali tak zwaną „Dzielnicę północną": Stare Miasto, Leszno, Muranów, Powązki, Mirów i Grzybów. Była to dzielnica pełna dynamizmu i egzotyki: na ulicach Dzielnej, Pawiej, Gęsiej, Franciszkańskiej, Miłej, Muranowskiej, Nalewkach - mieściły się setki sklepików i warsztatów, na chodnikach i w bramach tłoczyli się ubodzy przekupnie [Hen 2011]. Okupacja niemiecka, która miała miejsce na ziemiach polskich, spowodowała zagładę prawie całej mniejszości żydowskiej w Warszawie [Drozdowski, Sołtan, Zahorski 2017; Majewski 2019; Piechotka M., Piechotka K. 2004a; Piechotka M., Piechotka K. 2004b].

Historia Żydów w Warszawie jest dziś postrzegana głównie przez pryzmat Zagłady, gdyż zaledwie w ciagu kilku lat, między 1939 a 1943, ta bogata i barwna kultura miejska gminy została niemal doszczętnie zniszczona. Przetrwała głównie w pamięci ludzi, utworach literackich, fotografiach i filmach archiwalnych. Nieliczne materialne ślady kultury żydowskiej, które przetrwały, są dzisiaj ważnym świadectwem przeszłości. Należą do nich pojedyncze zabytki architektoniczne, cmentarze przy ul. Okopowej i na Bródnie, synagoga Nożyków, fragmenty murów getta, resztki chodników, które mogą być podstawą rozwoju turystyki kulturowej. Wymienione zabytki moga być uzupełniane niematerialnymi świadectwami, razem dając wyobrażenie o dziedzictwie kultury gminy żydowskiej w Warszawie, zarówno w wymiarze kultury życia codziennego, jak i „kultury wysokiej”. Chociaż jest prawda, że gmina warszawska nie miała tradycji historycznej tak bogatej, jaką miały społeczności żydowskie w Krakowie, Lublinie czy Lwowie - gdzie Żydzi żyli od pokoleń - nie wolno zapomnieć, że Żydzi zasłużyli się historii Warszawy pod względem gospodarczym i znaczących wysokich wartości kulturowych.

Ponieważ Warszawa była geograficznie i historycznie miastem położonym między Wschodem a Zachodem, w konsekwencji była miastem, w którym obok siebie żyły różne kultury: polska, żydowska, niemiecka i rosyjska. Warszawa prawdopodobnie bardziej niż inne polskie miasta była miejscem spotkań różnych religii i kultur. Wciąż o tym świadczą zachowane zabytki jej dzielnic, na przykład Pragi: bizantyjska katedra prawosławna św. Marii Magdaleny, barokowy kościół rzymskokatolicki Loreto, Synagoga Żydowska przy ul. Targowej 50/52. Wydarzenia II wojny światowej zniszczyły wielokulturowa mozaikę mieszkańców Warszawy, ale wciąż można ślady bogactwa historycznej wielokulturowości miasta odkrywać. Zachowane świadectwa przeszłości, chętnie poznaje młode pokolenie Polaków, Żydów oraz innych narodowości.

Znaczenie turystyki miejskiej ukierunkowanej na poznanie wartości kultury zostało rozeznane i opisane na podstawie badań naukowych przeprowadzonych w wielu ośrodkach akademickich [Dallen, Boyd 2003; Hall 2000]. Wynika z nich, że w większości krajów miejska turystyka kulturowa ma znaczący udział w PKB, wynoszacy pięć lub więcej procent [Sigala, Leslie 2006]. Teorie urbanistyki współczesnej zakładają słusznie, że przestrzeń miejska generuje różnorodne wartości kulturowe, istotne dla gospodarki, społeczeństwa i postępu cywilizacyjnego („ekonomia kultury”). Na przykładzie Warszawy, Krakowa i Gdańska widać rosnące znaczenie, w ciagu ostatnich trzech dekad (1989-2019), turystyki miejskiej, a zwłaszcza kulturowej turystyki miejskiej. 
Była to ważna przesłanka do podjęcia decyzji przez Wydział Turystyki i Rekreacji Akademii Wychowania Fizycznego Józefa Piłsudskiego w Warszawie (AWF) badań dotyczących uwarunkowań rozwoju turystyki miejskiej, opartej na zróżnicowanym dziedzictwie kulturowym miasta (projekt badawczy został wsparty grantem statutowym Ministerstwa Nauki i Szkolnictwa Wyższego: DS-144). Naszym celem było poszerzenie wiedzy na temat turystyki miejskiej w Warszawie oraz zbadanie znaczenia różnorodnego, wieloetnicznego dziedzictwa kulturowego dla zrównoważonego rozwoju turystyki. Wychodząc z tego założenia do planowanych studiów przypadku włączyliśmy dziedzictwo kultury żydowskiej, zarówno materialne, jak i niematerialne. $\mathrm{W}$ niniejszym artykule przedstawiono główne wyniki tej części badania. Należy wspomnieć, że badania dotyczące dziedzictwa żydowskiego w dzielnicy Praga w Warszawie wsparła także Europejska Fundacja Nauki (grant ESF SCH/SCSS EW 80), w ramach projektu „Exploring Creative Cities: The Cultural And Economic Values of Cultural Industries Clusters", koordynowanego przez prof. dra Erika Hittersa z Erasmus University Rotterdam, Wydział Historii Sztuki, Rotterdam (Holandia).

\section{Dziedzictwo żydowskie i turystyka kulturowa w Warszawie}

W swojej prawie 2000-letniej historii diaspory Żydzi byli obecni w Polsce od ośmiuset lat: od wczesnego średniowiecza do Holokaustu (okres II wojny światowej). Do czasów nam współczesnych przetrwała nieliczna grupa, szacowana na niespełna 10 tys. osób (tabela 2).

Tabela 2. Mieszkańcy Warszawy w latach 1864-2011 (ogółem i Żydzi)

\begin{tabular}{|c|c|c|c|c|c|c|c|}
\hline Rok & 1864 & 1882 & 1892 & 1901 & 1921 & 1938 & \multicolumn{1}{c|}{2011} \\
\hline Razem & 222906 & 382964 & 417421 & 569711 & 988713 & 1265372 & 1790658 \\
\hline Żydzi & 72776 & 127917 & 163232 & 254712 & 310334 & 368394 & 7353 \\
\hline
\end{tabular}

Źródło: M.M. Drozdowski, A. Sołtan, A. Zahorski, Historia Warszawy, Wydawnictwo Bellona, Warszawa 2017; GUS 2019; na podstawie Krajowych Ocen Publicznych w Polsce aż 7353 respondentów zadeklarowało się jako Żydzi (2011) [www.stat.gov.pl, 2021]

Należy podkreślić, że od innych grup mniejszości narodowych w Polsce, Żydów wyróżniały religia, język, obyczaje, sztuka i architektura. Większość Żydów mieszkała w sztetlach, tj. dzielnicach małych miast, w wielu regionach tworząc większość ludności i tworząc odrębne gminy rządzone według własnych praw. Jako że posiadali autonomię w obrębie swoich wspólnot, każdą z nich zarządzała grupa starszych kahałów, przy dużym wsparciu księży - rabinów. Od XIV w. do początku II wojny światowej Polska była znana jako kulturalne i duchowe centrum europejskich Żydów. Rozkwitało życie kulturalne i naukowe, talmudyczni badacze i studenci licznych akademii jesziwy cieszyli się dużym uznaniem w całym żydowskim świecie. W pierwszej połowie XVII w. powstał nowy typ murowanego budynku synagogi: z obszernym wnętrzem podzielonym na dziewięć części z bimą umieszczoną między czterema masywnymi filarami podtrzymującymi sklepienie. Zbudowano liczne 
drewniane synagogi z efektowna polichromią ścian i przedmiotami liturgicznymi - niestety żadna z nich nie zachowała się [Piechotka M., Piechotka K. 2004b]. W okresie międzywojennym w XX w. Polska była domem dla największej społeczności żydowskiej w Europie, wyróżniającej się ogromną żywotnościa gospodarcza, kulturową i intelektualna.

W Warszawie społeczność żydowska nie miała długiej tradycji. Warszawa nie miała kilkusetletnich synagog jak Kraków, stąd w zachowanych świadectwach brakuje zarówno dawnej zabudowy, jak i tradycji wielowiekowej przeszłości. Najstarszy budynek należący do Żydów w Warszawie datowany jest na 1811 r. (Synagoga Żydowska na Pradze, ul. Targowa 50/52). Dopiero od drugiej połowy XIX w. warszawska gmina żydowska zaczęła się dynamicznie rozwijać. Zbiegło się to $\mathrm{z}$ okresami rozkwitu gospodarczego w Warszawie, kiedy to rozwijał się przemysł i unowocześniano infrastrukturę techniczna miasta. Należy podkreślić, że szczególnie w drugiej połowie XIX w. żydowska klasa wyższa i średnia wywarły silny wpływ na życie kulturalne Warszawy [Majewski 2019]. Szereg bogatych, prominentnych rodów, takich jak Kronenberg, Natanson, Toeplitz i Wawelberg, stało się fundatorami licznych instytucji edukacyjnych i religijnych. Działały żydowskie biblioteki, czytelnie, kluby literackie i muzyczne, towarzystwa naukowe, teatry i kluby sportowe. Dobrze rozwinięta sieć instytucji charytatywnych pozwalała na finansowanie szpitali, domów starców i domów dziecka. Najbardziej okazałą synagogą w Warszawie była Wielka Synagoga na Tłomackiem. Ta synagoga była jedynym miejscem w Warszawie, w którym odbywały się specjalne „reformacyjne” nabożeństwa w języku polskim. To miejsce religijne odwiedzali głównie Żydzi z wyższych i średnich warstw społecznych oraz żydowska inteligencja. Inaczej było w Synagodze Nożyków, gdzie mówiono nie po polsku, tylko w jidysz. Piękny gmach Wielkiej Synagogi został zaprojektowany przez Leandro Marconiego i ukończony w 1878 r. Synagoga mogła pomieścić aż 2400 osób i miała dużą salę spotkań, archiwum, bibliotekę i szkołę. Główna Biblioteka Judaistyczna została wybudowana obok Wielkiej Synagogi na Tłomackiem w 1936 r., zaprojektowana w stylu semi-modernistycznym (eklektycznym). Główna Biblioteka Judaistyczna została ufundowana z datków ludności żydowskiej oraz dotacji miejskich. Jej projektantem był architekt Edward Zachariasz Eber (1880-1953) [Drozdowski, Sołtan, Zahorski 2017; Majewski 2019; Piechotka M., Piechotka K. 2004b]. Gmach Głównej Biblioteki Judaistycznej ucierpiał w czasie wojny, ale został odrestaurowany i ponownie otwarty w 1947 r. Obecnie mieści się w nim Żydowski Instytut Historyczny, którego misja jest gromadzenie i promocja dorobku kulturalnego Żydów. W jej archiwach znajduje się duży zbiór materiałów i dokumentów związanych z historią Żydów w Polsce. Żydowski Instytut Historyczny (ŻIH) w Polsce został ufundowany przez państwo w 1947 r. Biblioteka Instytutu działa pod auspicjami Polskiej Akademii Nauk, liczy ponad 60 tys. tomów literatury i starych rękopisów, pochodzących już z X w. Obejmuje ona także Podziemne Archiwum dra Emanuela Ringelbluma [jih.pl, 2020].

Przed II wojną światową Warszawa stała się największym skupiskiem ludności żydowskiej w Polsce, w 1937 r. liczyła ponad 350 tys., tj. prawie 40\% mieszkańców miasta. Warszawa była nazywana „stolicą świata języka jidysz”, a historyczna dzielnica żydowska zajmowała prawie 1/5 powierzchni miasta. Potocznie nazywano ją „Dzielnicą Północna” lub po prostu 
„Nalewkami”. Żydzi mogli osiedlać się we wszystkich częściach miasta, ale często wybierali dzielnicę północna, historyczny obszar getta, powstałego w Warszawie w czasie rozbiorów Polski (miasto leżało wówczas w zaborze rosyjskim). Z czasem, coraz liczniejsze zasymilowane, zamożne rodziny, osiedliły się także w innych częściach miasta, w tym w eleganckim centrum Warszawy (Aleje Jerozolimskie, ulice Marszałkowska, Nowogrodzka, Nowy Świat, Aleje Ujazdowskie). Znaczenie Warszawy wzrosło po odzyskaniu przez Polskę niepodległości w 1918 r., odtąd Warszawa była kulturalna stolicą diaspory żydowskiej w Europie. Mieszkało w niej wielu pisarzy, poetów i dziennikarzy piszących w jidysz. Na niektórych ulicach Dzielnicy Północnej (Nalewki) i Pragi - rzadko słyszało się inny język niż jidysz [Majewski 2019].

Choć dziedzictwo żydowskie zostało niemalże unicestwione przez nazistów w latach 1939-1943, kiedy prawie cała centralna i północna Warszawa stała się morzem gruzów, to wciąż istnieje kilka cennych śladów kultury materialnej, świadków historii [Drozdowski, Sołtan, Zahorski 2017; Majewski 2019] (ryc. 1-14). Pomimo bezprecedensowych zabiegów wymazania z pamięci, ocalały do czasów nam współczesnych nieliczne synagogi, cmentarze i budynki użyteczności publicznej. Należą do nich resztki muru getta, Synagoga Nożyków, Cmentarz Żydowski (założony w 1806 r., jeden z największych w Polsce, gdzie pochowano wielu wybitnych polskich Żydów jak L. Zamenhof), dawny Dom Dziecka dra Janusza Korczaka, nie wspominając o kilku XIX-wiecznych obiektach sakralnych, które przetrwały na Pradze, przy ul. Jagiellońskiej i Targowej.

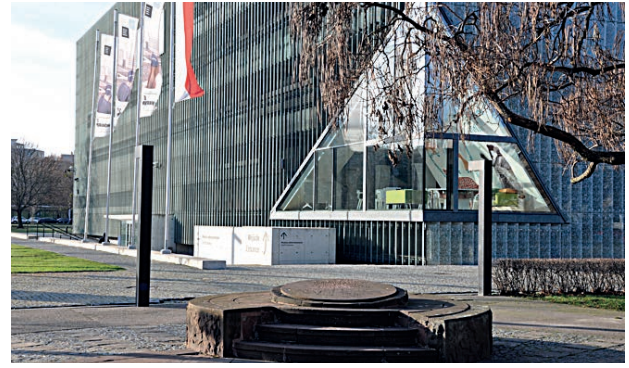

Ryc. 1. Wejście do Muzeum Historii Żydów Polskich POLIN w Warszawie Fot. A. Ostrowska-Tryzno, 2020

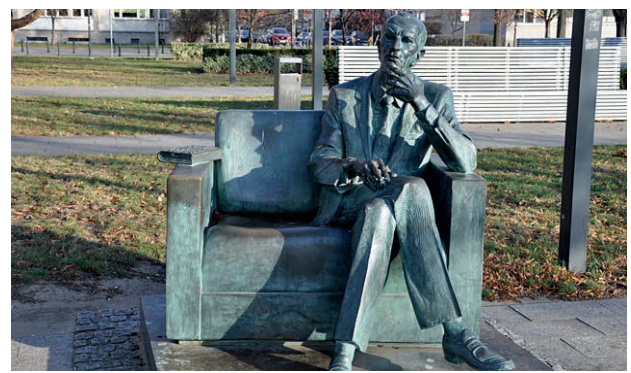

Ryc. 3. Pomnik Jana Karskiego, przy Muzeum Historii Żydów Polskich POLIN

Jan Karski był polskim żołnierzem i kurierem w czasie Il wojny światowej, który przygotowywał raporty o zniszczeniu przez Niemcy getta warszawskiego i nazistowskich obozów zagłady w okupowanej Polsce

Fot. A. Ostrowska-Tryzno, 2020 
Przed wybuchem II wojny światowej w Warszawie było aż 400 żydowskich domów modlitwy. Synagoga Nożyków jest jedyną zachowaną przedwojenna synagoga. Została wzniesiona w 1902 r. wg projektu architekta Karola Kozłowskiego w stylu neoromańskim z elementami ornamentyki bizantyjskiej. Powstała na zlecenie Zelmana Nożyka, zamożnego
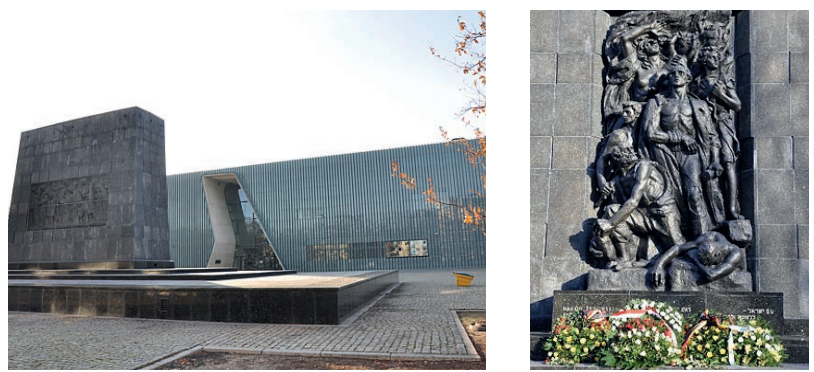

Ryc. 4. Widok na Pomnik Bohaterów Warszawskiego Getta oraz budynek Muzeum Historii Żydów Polskich POLIN w Warszawie, od strony ul. L. Zamenhofa

Fot. A. Ostrowska-Tryzno, 2020 kupca żydowskiego i jego żony Rywki. Synagoga Nożyków została odnowiona w latach 1977-1983. Dziś nabożeństwa odprawiane są codziennie i w najważniejsze święta żydowskie [Drozdowski, Sołtan, Zahorski 2017; Majewski 2019]. Najstarszy cmentarz żydowski został założony w 1799 r. na Bródnie. Został poważnie zniszczony w czasie II wojny światowej, a w 1985 r. przeprowadzono tam prace remontowe. Drugi cmentarz żydowski, przy ul. Okopowej, został założony na początku XIX w. Jest to największy cmentarz żydowski w Warszawie, na którym pochowano aż 250 tys. osób w 200 tys. grobach. Można znaleźć nagrobki słynnych Żydów, do których należy I.L. Perec (pisarz), Ester Kamińska (aktorka) i dr L. Zamenhof (twórca języka esperanto). Na Cmentarzu Żydowskim przy ul. Okopowej stoi też pomnik upamiętniający Janusza Korczaka [Drozdowski, Sołtan, Zahorski 2017; Majewski 2019].

Od końca XVIII w. społeczność żydowska Gminy Praskiej skupiała się przy ulicach Szerokiej i Petersburskiej (obecnie Jagiellońskiej i Kłopotowskiej). W 1836 r. wybudowano tam murowaną synagogę wg projektu architekta Josefa Lessla. Po II wojnie światowej w budynku mieściły się biura Centralnego Komitetu Żydowskiego w Polsce. W 1961 r., mimo że był w dobrym stanie technicznym, gmach został rozebrany. W przeszłości, większość warszawskich synagog były to małe, modlitewne domy (lub izby) usytuowane w mieszkaniach

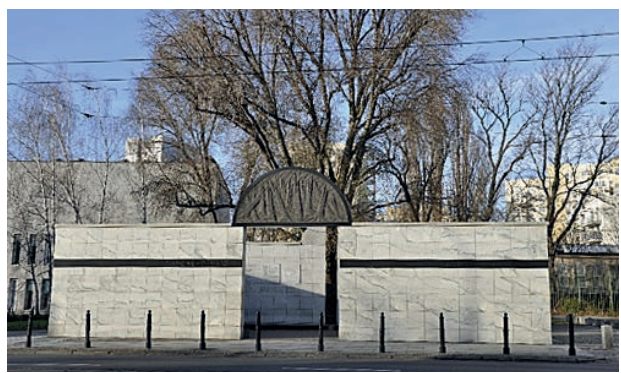

Ryc. 5. Umschlagplatz

Pomnik symbolizujący otwarty wagon towarowy dla upamiętnienia deportacji ofiar getta warszawskiego do hitlerowskich obozów zagłady w czasie Il wojny światowej, ul. Stawki, Warszawa

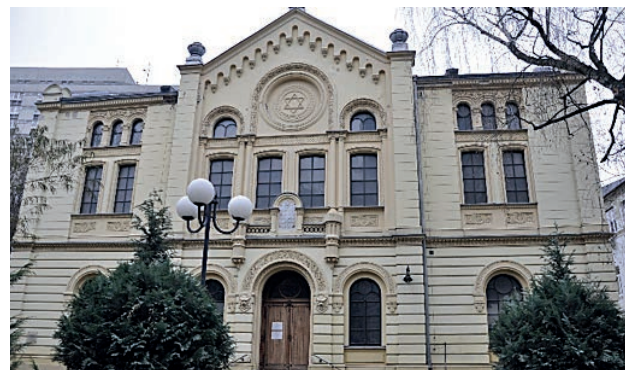

Ryc. 6. Synagoga Nożyków przy ul. Twardej 6 w Warszawie

Fot. A. Ostrowska-Tryzno, 2020

Fot. A. Ostrowska-Tryzno, 2020 

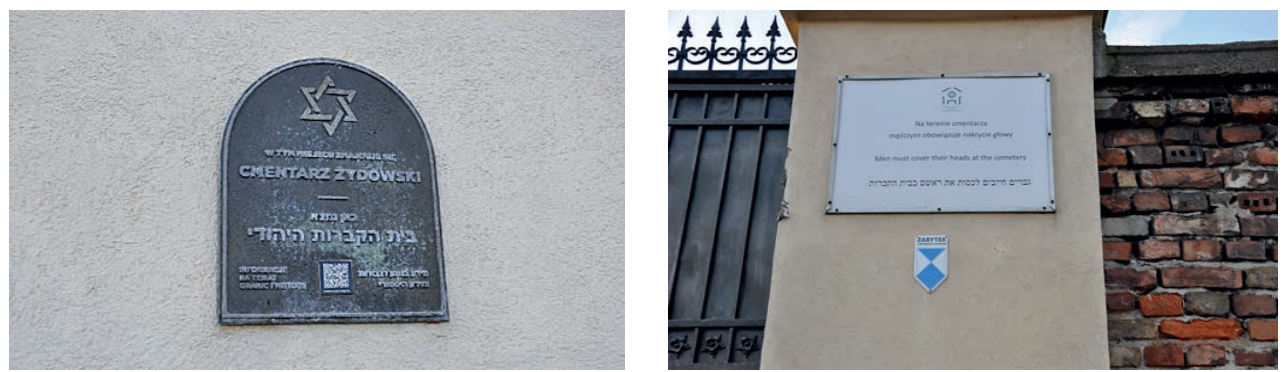

Ryc. 7., 8. Cmentarz żydowski przy ul. Okopowej w Warszawie

Fot. A. Ostrowska-Tryzno, 2020

lub na podwórkach kamienic. Niedawno jeden z takich domów modlitwy odkryto w starym budynku przy ul. Targowej 50/52. Został on wybudowany w 1811 r., a wewnattrz widoczne są fragmenty malowideł ściennych przedstawiających Ścianę Płaczu, Grób Racheli oraz znaki Zodiaku. Znacznie późniejszy napis w języku hebrajskim mówi, że obrazy zostały sfinansowane z darowizn w 1934 r. [Majewski 2019].

Kraków, Lublin i Warszawa były przez kilkaset lat głównymi ośrodkami kultury żydowskiej w Polsce, dziś te trzy miasta są licznie odwiedzane przez turystów krajowych i zagranicznych, wielu przyjeżdżających spoza Europy, ale twierdzacych, że mają tu swoje rodowe korzenie. Dlatego „Poland Jewish Tours”, „Warsaw Jewish Tours” czy „Warsaw - Krakow Jewish Tours" sa postrzegane nie tylko jako okazja do odwiedzenia miejsc historycznych, krajoznawcza turystyka miejska lub popularny wśród młodego pokolenia „city break”, ale także turystyka nostalgiczna: okazja do uczestniczenia $w$ tradycjach religijnych, do udzia-

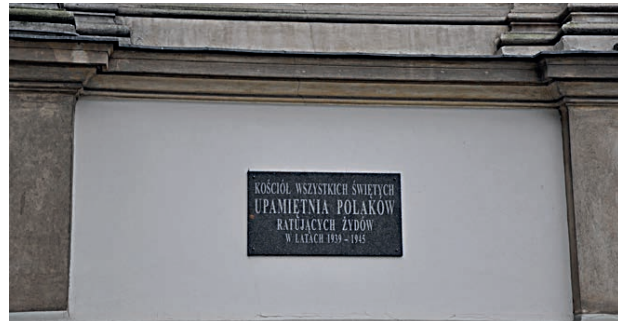

Ryc. 9. Kościół Wszystkich Świętych przy pl. Grzybowskim w Warszawie wraz z tablicą upamiętniająca Polaków ratujących Żydów w latach 1939-1945

Fot. A. Ostrowska-Tryzno, 2020 łu w wydarzeniach kulturalnych (festiwale żydowskie w Warszawie i Krakowie) czy historycznych uroczystościach takich jak Yom HaShoah, organizowanych 19 kwietnia - jako coroczna ceremonia upamiętniająca Powstanie w Getcie Warszawskim. Te grupy turystów, wśród nich także zorganizowane wycieczki młodzieży szkolnej z Izraela, sa ukierunkowane na edukacje, poznanie historii i tradycji Żydów w Polsce, nawet głębsze studia, w tym przeprowadzenia badań genealogicznych na temat historii i powiązań rodzinnych.

Przed 2020r. doświadczaliśmy bardzo wyraźnie odrodzenie kultury żydowskiejw Warszawie, renesans zainteresowania żydowskim dziedzictwem, materialnym i niematerialnym oraz tradycją. Ostatnio coraz popularniejszym wydarzeniem jest Festiwal Kultury Żydowskiej „Warszawa Singera”, który upamiętnia rocznicę urodzin Izaaka Bashevisa Singera. Bogaty program wydarzenia obejmuje koncerty muzyczne, wystawy, przedstawienia teatralne etc. 


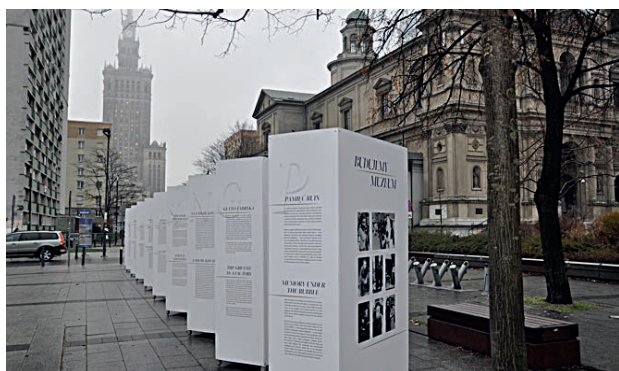

Ryc. 10. Wystawa plenerowa prezentująca życie codzienne w Gettcie w 1943 r.

Istalacja na pl. Grzybowskim w Warszawie

Fot. A. Ostrowska-Tryzno, 2020

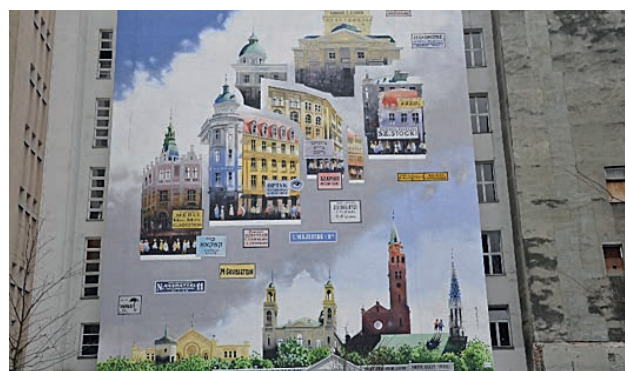

Ryc. 11. Mural „Warszawa żydowska” Tytusa Brzozowskiego ul. Próżna 12 w Warszawie Fot. A. Ostrowska-Tryzno, 2020

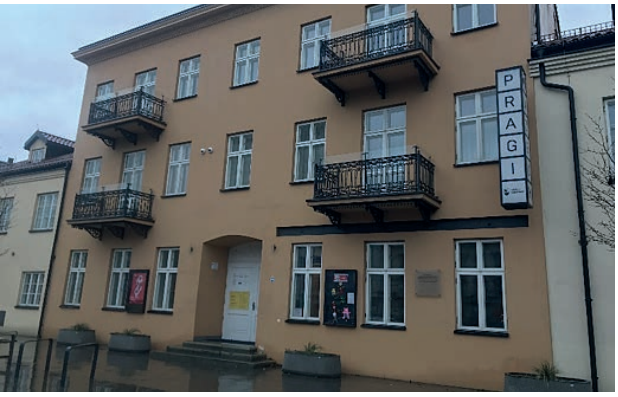

Ryc. 12. Muzeum Pragi (dawny dom modlitwy) ul. Targowa 50/52 w Warszawie

Fot. A. Ostrowska-Tryzno, 2020 Muzeum POLIN oraz długa kolejka chętnych do odwiedzenia Synagogi Nożyków podczas corocznej „Nocy Muzeów” są tego najlepszym dowodem [nimoz.pl, 2020], (tabela 1). Nie trzeba dodawać, że poznawanie wspólnej kultury i tradycji jest najlepszym sposobem na poprawę relacji, na budowanie tolerancji i zrozumienia. Turystyka opiera się na interakcji między ludźmi i jest ważnym narzędziem promocji kultury i dialogu międzykulturowego.

\section{Turystyka kulturowa a ograniczenia pandemiczne}

W obu dekadach XXI w. obserwujemy w skali wszystkich miast Europy, także w Warszawie, stały wzrost turystyki kulturowej i jej różnych form - turystyka etniczna, turystyka festiwalowa. Rozwój turystyki międzynarodowej jest ściśle powiązany z procesami globalizacji. Stopniowa liberalizacja handlu międzynarodowego, ułatwianie podróży zagranicznych, rosnąca liczebność klasy średniej i jej dochody pozytywnie wpłynęły na rozwój turystyki masowej - międzynarodowej i krajowej. W 2019 r. UNWTO szacowało ruch turystyki międzynarodowej na 1,5 miliarda ludzi, prognozując wzrost o 4\% w 2020 r. jako 


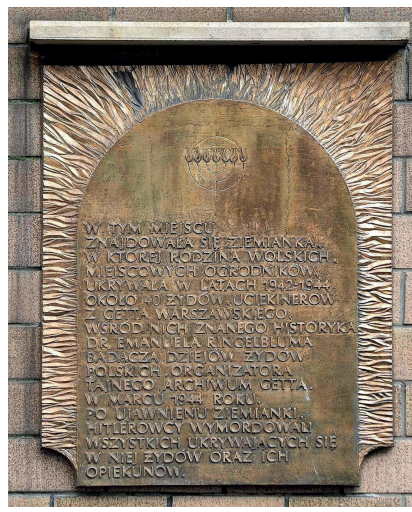

Ryc. 13. Tablica pamięci mieszkańców Getta zamordowanych przez nazistów, w tym E. Ringelbluma, przy ul. Grójeckiej w Warszawie

Żródło: A. Grycuk, 2014, GNU Free Documentation

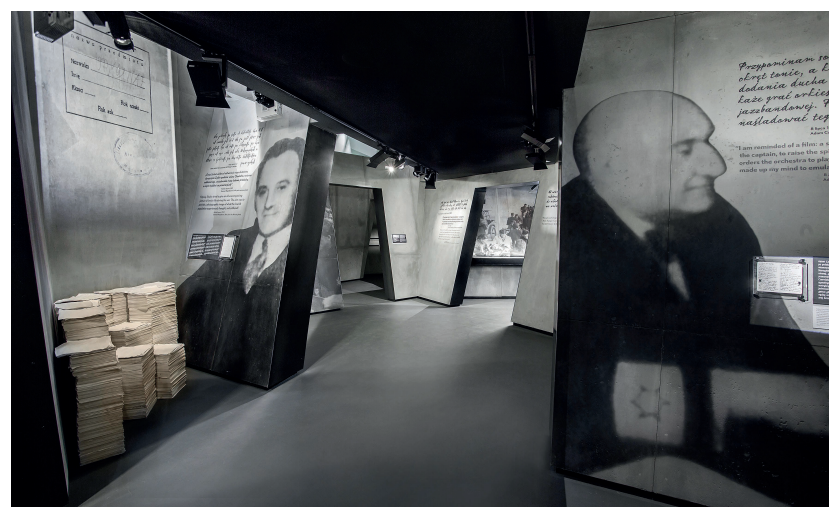

Ryc. 14. Wnętrze wystawy archiwum E. Ringelbluma Muzeum POLIN

Źródło: M. Starowieyska, D. Golik, 2020, GNU Free Documentation

oczywistą kontynuację trendu, który trwa od dekady. Jeszcze na początku 2020 r. świat nauki i ekspertów obawiał się nadmiernego rozwoju turystyki w przyszłości (zjawiska overtourism) i szeregu wynikających z tego zagrożeń, przede wszystkim dla środowiska przyrodniczego i kulturowego. W przygotowanym przez UNWTO dokumencie „Dekada Działań 20202030" sformułowano 17 zasad zrównoważonego rozwoju turystyki w kolejnej dekadzie, aby przeciwdziałać tym negatywnym zjawiskom.

W 2020 r. wybuch pandemii COVID-19 mocno uderzył w sektor turystyczny i nadal obowiązują liczne ograniczenia w podróżowaniu. Niezbędna jest zatem weryfikacja starych prognoz i przygotowanie nowych rekomendacji kierunków rozwoju turystyki kulturowej. W czerwcu 2020 r. UNWTO przygotowało dokument „Tourism Recovery Post COVID-19”, którego motto brzmi: „Zostań dzisiaj w domu. Podróżuj jutro”. Wyróżnia trzy filary, które determinują ożywienie turystyki (na poziomie globalnym, krajowym, regionalnym i lokalnym): zdrowie, bezpieczeństwo i odbudowę zaufania konsumentów. Pakiet pomocy technicznej UNWTO „COVID-19 Tourism Recovery” koncentruje się na trzech głównych filarach: ożywieniu gospodarczym, marketingu i promocji, wzmocnieniu instytucjonalnym i budowaniu odporności. Na tym krytycznym etapie „Pakiet Odnowy Turystyki” obejmuje działania i strategie ukierunkowane na długi czas, średnioterminowe oraz rozwiązania, które moga być wdrożone natychmiast (np. programy pomocy technicznej, szkolenia) w zależności od konkretnej sytuacji i potrzeb [UNWTO 2020]. 
W dokumencie „Travel Tomorrow and Share Culture” przygotowanym przez Europejska Sieć Turystyki Kulturalnej [ECTN 2020] podkreślono, że turystyka kulturowa będzie prawdopodobnie głównym motorem ożywienia sektora turystyki w Europie. Wyróżniono w nim następujące pilne działania, jakie powinny podjąć instytucje zajmujące się rozwojem i promocją turystyki kulturowej:

- Regularnie aktualizowana i dostosowywana informacja i promocja, docieranie do jak najszerszego grona odbiorców, poszukiwanie nowych odbiorców;

- Ustawiczne wdrażanie innowacyjnych technologii, w tym nacisk na wirtualne komunikaty, wyrażone hasłem „Dzisiaj odwiedzający muzeum online, jutro mogą pojawić się w rzeczywistości";

- Uwzględnianie konieczności wielu zmian, w tym dostosowanie istniejących strategii handlowych, zakresu i charakteru oferowanych usług turystycznych; pojawiajace się zmiany wymuszone sa głównie potrzebą zapewnienia bezpieczeństwa sanitarnego;

- Podejmowanie działań naprawczych wspólnie z administracją rządową i samorządowa, organizacjami pozarządowymi, fundacjami, lokalnymi działaczami kultury i organizatorami turystyki.

W 2020 r. ponad 80\% muzeów na całym świecie zostało zamkniętych, ale miliony turystów podczas blokady wirtualnie odwiedzały muzea i miejsca z Listy Światowego Dziedzictwa UNESCO [ECTN 2020; UNWTO 2020]. W 2020 r., kiedy muzea w Warszawie zostały zamknięte w wyniku decyzji rządu, wyraźnie widać było duże zapotrzebowanie na wirtualny dostęp do muzeów i zabytków. Pomimo poważnych wyzwań sektor kultury próbował stworzyć nowa ofertę, przyciagnać nowych odbiorców, wypracować nowe atrakcje. W warszawskim Muzeum POLIN pojawiło się kilka propozycji wirtualnych wizyt, jak na przykład „Muzeum POLIN w Twoim domu” czy „Wirtualna podróż po wystawie stałej”, specjalny wybór tras, oprowadzanie z przewodnikiem po wystawie, nagrań audiowizualnych, umożliwiających zwiedzanie muzeum on-line [polin.pl 2020]. W 2020 r. Muzeum Gminy Pragi w Warszawie, powstałe w dawnym żydowskim domu modlitwy, oferowało wirtualne spacery oraz bezpłatne wirtualne lekcje muzealne dla młodzieży szkolnej z wykorzystaniem platformy ZOOM [muzeumwarszawy.pl]. Jak się uważa, oferty te mogą wzbudzić zainteresowanie zwiedzaniem obiektu w realnej rzeczywistości. Oczekiwanie to wyraża i podsumowuje hasło spotu przygotowanego wspólnie przez UNWTO i CNN w 2020 r., emitowanego na wielu kanałach i w wielu krajach - „Zaplanuj wyjazdy marzeń już dziś, jutro będzie wyjazd".

Wychodząc naprzeciw pandemii, w 2020 r. Agencja Warsaw City Tours zaproponowała prywatne, niestandardowe wycieczki skierowane do małych grup i turystów indywidualnych. Oferowano m.in. zwiedzanie miasta z wykorzystaniem specjalnego transportu: rowerów lub autobusów zapewniających odpowiedni dystans między pasażerami oraz bezpieczeństwo sanitarne. Turyści mogli spodziewać się płatności kartą zbliżeniowa, masek na twarz dostępnych dla uczestników wycieczki i personelu, zachowaniem reżimu sanitarnego zgodnie z wymaganiami dla miejsc publicznych, odkażonych pojazdów transportowych ze stanowiskami do dezynfekcji rakk, dystansu społecznego, regularnych kontroli temperatury 
personelu [warsawcitytours.pl]. Są to przykłady opracowanych już i wdrożonych strategii krótkoterminowych ${ }^{1}$.

Przedstawiciele poszczególnych sektorów branży turystycznej w wielkich miastach (hotele, gastronomia, muzea) starali się jak najśpieszniej dostosować do reżimów sanitarnych obowiązujących w czasie pandemii. Warto jednak także rozważyć również inne, średnioi długoterminowe działania, opracowane przez UNWTO w 2020 r. Zawierają one rekomendacje tak szczegółowe, jak propozycja tarcz ochronnych dla recepcji w hotelu, ale również rekomendacje o charakterze ogólnym: współpraca ze Światową Organizacją Zdrowia, wymiana informacji i danych pomiędzy sektorami turystyki, sojusze innowacyjne, bardziej zrównoważona przyszłość turystyki kulturowej, lepsza koordynacja i wymiana informacji (pomiędzy strukturami rządowymi, lokalnie i na arenie międzynarodowej), przyciaganie szerokiego grona odbiorców (wszystkie grupy społeczne: dzieci, młodzież, seniorzy).

Wśród możliwych do natychmiastowego wdrożenia strategii odbudowy turystyki kulturowej i adaptacji do sytuacji pandemicznej, pomocne mogą być proste i praktyczne rozwiązania, takie jak: restrykcje sanitarne i protokoły sprzątania w muzeach i obiektach zabytkowych, standardy bezpieczeństwa zdrowotnego w restauracjach i hotelach (zachowanie bezpiecznej odległości i limity obłożenia, osłony sanitarne, mycie rąk, dezynfekcja), ograniczenie interakcji osobistych na rzecz nowych technologii, w celu ograniczenia kontaktu bezpośredniego i redukcji ryzyka zakażenia. W perspektywie średnio- i długoterminowej pomocne mogą być dalsze strategie poprawy bezpieczeństwa sanitarnego i przywrócenia zaufania do podróżowania, jak np. zaawansowane technologie, roboty, sztuczna inteligencja. Wszystkie te zabiegi wymagają dobrze skoordynowanej współpracy publiczno-prywatnej, aby umożliwić ponowne otwarcie: hotelu, lokalu gastronomicznego, muzeum. Należy sobie zdawać sprawę, że te nowe procedury i wyzwania moga znacząco podnieść ceny i wpłynąć na stabilność biznesu. Niektórzy eksperci wierzą w pełny powrót do przedkryzysowych wzorców i nawyków podróżowania, choć niektórzy przewidują, że turysta może preferować wyższe standardy bezpieczeństwa zdrowotnego również w przyszłości, po zniesieniu formalnych ograniczeń pandemicznych [Assaf, Scuderi 2020; Burni 2020; Iguman 2020; UNWTO 2020].

\footnotetext{
${ }^{1}$ Od momentu powstania artykułu do chwili obecnej biura turystyczne znacznie rozszerzyły swoje propozycje. Aktualnie możemy znaleźć oferty skierowane do turystów zagranicznych, np. Private Tour: Warsaw's Jewish Heritage by Retro Fiat - Viator (Viator); Taube Jewish Heritage Tours (Jewish Historical Institute, Taube Foundation, Warsaw); Jewish Warsaw Free Walking Tour by Walkactive (Walkactive); skierowane do gości krajowych i zagranicznych, np. Warsaw Ghetto Remains \& History Walking Tour; Private Jewish Warsaw Tour (Zwiedzanie Żydowskiej Warszawy - małe grupy); Jewish Heritage in Warsaw (Dziedzictwo Żydowskie Warszawy) (Warsaw City Tours by Łukasz); Warszawa: 4-godzinna prywatna wycieczka po żydowskim dziedzictwie (3 osoby), (Get Your Guide); Warsaw: Jewish Heritage 4-Hour Private Tour (Get Your Guide) lub skierowane do turystów krajowych, np. Zwiedzanie Warszawy - Żydowska Warszawa (biura: Grace Tour, Warszawa; Warszawa z Pasja, Warszawa); Wycieczka po Warszawie śladami Żydów (biuro AB Poland Travel, Warszawa). Warto podkreślić, że każde z wymienionych biur ma zakładkę "COVID" i wyjaśnione zasady bezpiecznego organizowania wycieczek oraz aktualnych reżimów sanitarnych obowiązujących w miejscach publicznych w Warszawie.
} 


\section{Podsumowanie i dyskusja}

Szeroka definicja dziedzictwa kulturowego implikuje złożoność i różnorodność turystyki związanej z tymi walorami. Jak się wydaje, dla turystów wielką atrakcją jest nie tylko dobrze zachowana historyczna tkanka urbanistyczna, zabytkowe zabudowania, działalność instytucji sztuki i kultury - dziedzictwo wyrażane przez materialne artefakty - ale także różnorodność tradycyjnej gastronomii, lokalnych dialektów, tradycyjnych obrzędów, festiwale, piosenki, anegdoty (prezentowane przez przewodników turystycznych). Wydaje się, że warszawskie dziedzictwo kultury żydowskiej doskonale wpisuje się w te oczekiwania.

Ostatnio nastapiło odrodzenie zainteresowania dziedzictwem kulturowym, w tym żydowskim i wielu turystów, zarówno krajowych, jak i zagranicznych chce poznać tę kulturę i zachowane zabytki przeszłości. Należy pamiętać, że również dzięki temu zainteresowaniu i licznym grupom turystycznym odwiedzającym Warszawę, których głównym celem było zwiedzanie miejsc związanych z historia i kultura żydowska, wiele zrobiono na rzecz restauracji zabytków architektury żydowskiej, często w wyniku dobrowolnych inicjatyw i wsparcia finansowego z różnych źródeł. Należy podkreślić, że dziedzictwo żydowskie w Warszawie może być istotną platformą kształtowania lepszego zrozumienia naszej 800-letniej historii współdzielenia przestrzeni wielokulturowej. Takie doświadczenie wydaje się szczególnie ważne dla pokoleń polskich, niemieckich, rosyjskich i izraelskich grup szkolnych odwiedzających nasze miasto. Co więcej, warszawskie dziedzictwo żydowskie jest często częścią popularnego programu wycieczek objazdowych, organizowanych przez biura podróży w Europie Środkowej (Warszawa-Kraków-Budapeszt i Praga), ukazując jeszcze szerszą perspektywę obecności Żydów w Europie, tak chętnie odkrywaną dziś przez młode pokolenie, nie tylko Europejczyków.

Chociaż niniejszy artykuł miał na celu zbadanie szerokiego zakresu zagadnień związanych z dziedzictwem żydowskim Warszawy oraz zrównoważoną, bezpieczną turystyką w czasie pandemii, nie można z pewnością twierdzić, że obejmuje wszystkie aspekty turystyki kulturowej. Wiele związanych z tą problematyką zagadnień wykracza już poza nasz zakres badawczy. Naszą intencją było zwrócenie uwagi na wagę i znaczenie turystyki kulturowej opartej na materialnej i niematerialnej kulturze żydowskiej, uwarunkowania jej kontynuacji w czasach pandemii. W tym mieściły się rozważenie szans i kierunków rozwoju w przyszłości, identyfikacja tych istotnych kwestii, które są istotne dla rewitalizacji turystyki kulturowej, podczas i po pandemii COVID-19, w krótkiej, średniej i długoterminowej perspektywie.

W toku tych rozważań pojawia się ważne pytanie, czy i jak możemy zaplanować rozwój i przebudowę turystyki kulturowej po kryzysie pandemicznym? Kiedyś planowanie, nawet $\mathrm{w}$ drobnych szczegółach było powszechną praktyka, teraz zdajemy sobie sprawę, na podstawie doświadczeń 2020 i 2021 r., że wiele czynników jest nieprzewidywalnych i planowanie rozwoju turystyki jest trudne, jeśli wręcz niemożliwe. Jedyną odpowiedzia, jak się wydaje, ale o charakterze jedynie ogólnym, jest elastyczność, gotowość do zmian i szybkie dostosowywanie się do nowych okoliczności, a nawet konieczność improwizacji do pewnych granic. Kreatywność, wyobraźnia, innowacje i nowe technologie mogą być bardzo pomocne w kształtowaniu nowej oferty turystyki kulturowej, skutecznym wdrażaniu ograniczeń sanitarnych i realizacji programu zwiedzania. Niezbędna jest zatem weryfikacja starych prognoz 
i przygotowanie nowych rekomendacji kierunków rozwoju turystyki kulturowej. Należy podkreślić, że planowanie przebudowy turystyki kulturowej wymaga rozwiązania kilku problemów, takich jak zapewnienie bezpiecznych pod względem sanitarnym hoteli, restauracji, handlu detalicznego, transportu publicznego, bezpiecznych sal muzealnych. Majacc to na uwadze, trudno będzie sformułować ogólne, obowiązujące wszystkich rozwiązania i być może każde miasto i każdy obiekt zabytkowy trzeba będzie przygotować indywidualnie.

W celu odbudowy zaufania konsumentów i umożliwienia odrodzenia turystyki kulturowej istotne moga być: nowa organizacja podróży, regulacje prawne, ograniczenia w celu zapewnienia bezpieczeństwa zdrowotnego (zwiedzanie, jak to obecnie oferuje agencja Warsaw City Tours), zaawansowane technologie (wirtualne wycieczki po muzeach i zabytkach) oraz działania ograniczone tylko do tych, które mogą odbywać się na zewnątrz.

Aby jednak było to możliwe, kluczowe mogą być działania rządu wspierające te strategie: branża turystyczna (hotele, restauracje, transport, biura podróży) i instytucje kultury (muzea, zabytki) potrzebuja wiarygodnych działań skoncentrowanych na: niskooprocentowanych/ darmowych pożyczkach, pożyczkach gwarantowanych, dotacjach bezzwrotnych, wyasygnowaniu środków na rozwój marketingu, na wzmocnienie tożsamości kulturowej, na organizację bezpłatnych webinariów i szkoleń, na pomoc w adaptacji i wdrażaniu nowych technologii (audio-video tours), na wsparcie w tworzeniu intensywnej promocji. Należy zauważyć, że odrodzenie turystyki kulturowej wymaga silnego wsparcia na poziomie krajowym i międzynarodowym, programów pomocy technicznej za pośrednictwem odpowiednich instytucji międzynarodowych, takich jak Światowa Organizacja Turystyki (UNWTO), Światowa Organizacja Zdrowia (WHO), Europejska Sieć Turystyki Kulturalnej (ECTN) oraz Organizacja Społeczno-Kulturalna Narodów Zjednoczonych ds. Edukacji (UNESCO).

Zdaniem ekspertów rok, dwa przerwy w turystyce znacznie wzmocni apetyt na zwiedzanie i podróżowanie [ECTN 2020; UNWTO 2020]. Jednak prawdopodobnie będa to inne warunki podróżowania, wypoczynku i zwiedzania, niż te, z którymi dotychczas mieliśmy do czynienia i być może dominować będzie inny typ turysty, np. krajowy, a nie międzynarodowy, mniej seniorów, a więcej młodzieży i dzieci. Czy będzie to turysta zainteresowany profilem $3 S$ „Sun Sea Sand”, czy raczej turystyką kulturową - wyrażaną przez 3E „Education Entertainment Experience", a może ich kombinacją?

Zależy to od rozwoju pandemii, ale także od działań marketingowych i budowania zaufania klientów - i można o to zadbać już teraz, umiejętnie kontrolując przekaz informacyjno-promocyjny, traktując lata 2020-2021 jako „podarowane” na naukę, zdobywanie nowych umiejętności, szukanie inspiracji, możliwości zmian $\mathrm{w}$ firmie i profilu usług turystycznych. Na stronie UNWTO codziennie odbywają się zdalne seminaria, wykłady i webinaria poświęcone tej kwestii [UNWTO 2020].

Potrzeba odbudowy struktury obsługi ruchu turystycznego po fali bankructw wywołanych pandemią i blokadą podróży nie jest jednak jedynym problemem, z jakim przyjdzie się zmierzyć władzom wielkich miast, w tym Warszawy.

Inną kwestią są bowiem pytania, czy jest możliwy i pożądany (po opanowaniu pandemii) powrót do ruchu turystycznego w wielkich miastach w skali sprzed 2020 r.? Czy mieszkańcy wielkich miast życzą sobie kontynuacji turystyki masowej w miejscu swojego zamieszkania? 
Mieszkańcy Barcelony, Madrytu, Wenecji, a w Warszawie, Krakowie i Gdańsku - mieszkańcy Starego Miasta od wielu lat protestowali przeciwko nadmiernemu ruchowi turystycznemu (zjawisko overtourismu), domagając się od swoich władz lokalnych wprowadzenia ograniczeń systemowych i prawnych. Alarm podnosili także konserwatorzy zabytków, zwracając uwagę na niebezpiecznie zadeptywane przez tłumy turystów, zagrożone historyczne części miast oraz kustosze obleganych przez turystów ponad miarę wytrzymałości muzeów.

Bez watpienia istnieje obecnie pilna potrzeba refleksji na temat kształtowania przyszłej polityki turystycznej w wielkich miastach, szukania kompromisu między masową turystyką na granicy wytrzymałości przestrzeni kulturowej miast i ich stałych mieszkańców a turystyką elitarna, dostępną tylko dla nielicznych, bardzo majętnych osób.

\section{Literatura}

Assaf A., Scuderi R., 2020, COVID - 19 and the recovery of the tourism industry, Tourism Economics, 26, 5, s. 731-733, DOI: doi.org/10.1177/1354816620933712

Burni F. (red.), 2020, Tourism facing a pandemic: from crisis to recovery, University of Bergamo, Bergamo, DOI: 10.6092/978-88-97253-04-4

Główny Urząd Statystyczny, 2020, Kultura w 2019 r., GUS, Warszawa, Kraków.

Główny Urząd Statystyczny, 2021, Rocznik Statystyczny m.st. Warszawy, GUS, Warszawa.

Dallen J.T., Boyd T.S., 2003, Heritage Tourism, $1^{\text {st }}$ Edition, Prentice Hall, NJ, USA.

Drozdowski M.M., Sołtan A., Zahorski A., 2017, Historia Warszawy, Wydawnictwo Bellona, Warszawa.

European Economic and Social Committee, 2005a, Contribution of tourism to the socio-economic recovery of areas in decline.Declaration of Cordoba, $1^{\text {st }}$ Edition, EESC Pamphlet Series, Brussels.

European Economic and Social Committee, 2005b, Tourism policy in the enlarged European Union. Katowice Declaration, $1^{\text {st }}$ Edition, EESC Pamphlet Series, Brussels.

Finn M., Elliott-White M., Walton M., 2000, Tourism and Leisure Research Methods. Data collection, analysis, evaluation and interpretation, Pearson-Longman, Harlow.

Hall C.M., 2000, Tourism Planning, Policies, Process and Relationships, Prentice Hall, NY.

Hen J., 2011, Nowolipie. Najpiękniejsze lata, Wydawnictwo W.A.B., Warszawa.

Herman K., Drozda Ł., 2021, Green Infrastructure in the Time of Social Distancing: Urban Policy and the Tactical Pandemic Urbanism, Sustainability, 13, 4, s. 16-31, DOI: 10.3390/su13041632 (Sustainable Special Issue: Landscapes in the Time of Social Distancing: Pandemic and Design of the Urban Environment, February 2021). 
Iguman S., 2020, If visitors will not go to Heritage, Heritage must go to visitors. Digitalisation Heritage in time of Corona [w:] F. Burni (red.), Tourism facing a pandemic: from crisis to recovery, University of Bergamo, s. 165-175, DOI: 10.6092/978-88-97253-04-4

Inskeep E., 1991, Tourism Planning: an Integrated and Sustainable Development Approach, John Wiley \& Sons, Inc., NY.

Law C.M., 1996, Urban Tourism. Attracting visitors to large cities, $3^{\text {rd }}$ Edition, Mansell, London.

Loyke L., Edmunds J., 2007, Key Concepts in Tourism, $1^{\text {st }}$ Edition, Palgrave-Macmillan, NY.

Majewski J.S., 2019, Warszawa nigdy nieodbudowana. Żydowski Muranów i jego otoczenie, Agora SA, Warszawa.

Piechotka M., Piechotka K., 2004a, Oppidum Judaeorum, Krupski i Ska, Poznań.

Piechotka M., Piechotka K., 2004b, Bramy Nieba - synagogi drewniane na terenach Polski i Litwy, Krupski i Ska, Poznań.

POLIN Muzeum Historii Żydów w Polsce, 2019, Raport roczny 2018, Warszawa.

Sigala M., Leslie D., 2006, The International Cultural Tourism: Management, implication and cases, $2^{\text {nd }}$ Edition, Elsevier, UK.

Smith M.K., 2006, Issues on Cultural Tourism Studies, $2^{\text {nd }}$ Edition, Rutledge, London.

Urząd Miasta Warszawy, 1993, Plan zagospodarowania przestrzennego Warszawy, TUP, Warszawa.

Williams S., 2003, Tourism and Recreation, $1^{\text {st }}$ Edition, Prentice Hall, Harlow.

World Tourism Organization UNWTO, 2005, City Tourism and Culture, UNWTO, Madrid.

\section{Źródła internetowe}

www.ectn.org (European Cultural Tourism Network), [dostęp w: 2020]

www.jih.pl (Żydowski Instytut Historyczny), [dostęp w: 2020]

www.muzeumwarszawy.pl (Praga Muzeum, Warszawa), [dostęp w: 2019, 2020]

www.nimoz.pl (Narodowy Instytut Muzealnictwa i Ochrony Zbiorów), [dostęp w: 2020]

www.polin.pl (Muzeum Polin w Warszawie), [dostęp w: 2019, 2020]

www.stat.gov.pl (Główny Urząd Statystyczny GUS), [dostęp w: 2019, 2020]

www.um.warszawa.pl (Urząd Miasta Warszawa), [dostęp w: 2021]

www.unesco.org (United Nations Education and Science Organization), [dostęp w: 2020]

www.unwto.org (UN World Tourism Organization), [dostęp w: 2020]

www.warsawcitytours.pl (Warsaw City Tours Agency), [dostęp w: 2020] 


\title{
Multicultural heritage as a basis for sustainable development of urban tourism in Warsaw - COVID-19 pandemic time
}

\begin{abstract}
Introduction: The importance of multiculturalism for the development of tourism, consistently emphasized in the literature, shows the long history and rich tradition of this form of tourism. Poland has historically been a land of transition between East and West, a land where different cultures have existed side by side: Polish, German, Jewish, and Russian. For centuries Poland was a meeting place of different religions and cultures and today's landscape still shows evidence of this. The catastrophe of World War II brought the annihilation of a multicultural society and created a homogeneity, unprecedented in our history. Jewish heritage and urban cultural tourism: In their almost 2000-year diaspora, Jews have been present in Poland for eight hundred years: from the early middle ages until the Holocaust, the annihilation during World War II. The Jews were distinguished from other community groups by their religion, language, customs, art and architecture. In the interwar period of the $20^{\text {th }}$ century, Poland was home to the largest Jewish community in Europe, distinguished by its enormous cultural and intellectual vitality. The preserved tangible and intangible traces of multicultural heritage in Warsaw became the basis for the development of cultural tourism. Pandemic time: The outbreak of the COVID-19 pandemic has hit the tourism sector hard, and travel restrictions still apply to us. Therefore, it is necessary to verify the forecasts and prepare new recommendations for cultural tourism destinations during and after the pandemic. Conclusions: Recently there has been a revival of interests in Jewish heritage and many tourists (both domestic and foreign) want to explore Jewish culture and remaining monuments of the past. Despite pandemic time restrictions it is also possible, however new actions and policy are required to secure sanitary recommendations and rebuild consumer confidence.
\end{abstract}

Key words: multicultural heritage, urban tourism, cultural heritage of Jews, COVID-19 pandemic time 


\begin{abstract}
Anna Ostrowska-Tryzno - dr nauk o kulturze fizycznej, adiunkt w Katedrze Turystyki i Rekreacji Wydziału Wychowania Fizycznego Akademii Wychowania Fizycznego w Warszawie. Specjalizuje się w problematyce turystyki biznesowej oraz uczestnictwie w turystyce i rekreacji grup społecznych izawodowych, w tym osób z niepełnosprawnościami. Aktualnie koncentruje swojq aktywność badawczq na zagadnieniach z zakresu zrównoważonego rozwoju miast, z uwzględnieniem aspektu turystyki kulturowej oraz zrównoważonego rozwoju turystyki biznesowej.

Kontakt: Katedra Turystyki i Rekreacji, WWF AWF Warszawa

e-mail:anna.tryzno@gmail.com

ORCID 0000-0002-2539-7900

Anna Ostrowska-Tryzno - PhD in physical culture, assistant professor at the Faculty of Tourism and Recreation at the Józef Piłsudski University of Physical Education in Warsaw. She specializes in the issues of business tourism and participation in tourism and recreation of social and professional groups, including people with disabilities. Currently, she focuses her research activity on the issues of sustainable urban development, including the aspect of cultural tourism and the sustainable development of business tourism. Contact: Faculty of Tourism and Recreation, Józef Piłsudski University of Physical Education in Warsaw e-mail:anna.tryzno@gmail.com ORCID: 0000-0002-2539-7900
\end{abstract}

Anna Pawlikowska-Piechotka, prof. dr hab. inż. arch. - absolwentka Wydziału Architektury Politechniki Warszawskiej. Od wielu lat zwiq̨zana z Wydziałem Turystyki i Rekreacji Akademii Wychowania Fizycznego Józefa Piłsudskiego w Warszawie oraz Wydziałem Architektury Politechniki Warszawskiej. Specjalizuje się w badaniach na temat zrównoważonego rozwoju terenów sportu, rekreacji i przestrzeni turystycznej. Brała udział w kilkunastu wieloośrodkowych, międzynarodowych projektach badawczych w kraju i zagranica. Autorka ponad dwustu artykułów naukowych, książek, skryptów, kilkudziesięciu ekspertyz; współautor opracowań planistycznych (architektura, urbanistyka) oraz kilku zgłoszonych wzorów patentowych (urzqdzenia dla osób niepełnosprawnych). Uczestniczyła aktywnie i wygłaszała referaty na kilkudziesięciu konferencjach organizowanych przez zagraniczne ośrodki akademickie oraz na kilku konferencjach ONZ (UN Habitat II, UN WTO). Wykładowca i uczestnik wymiany naukowej z: University College of Birmingham (WIk. Brytania), University of Evora (Portugalia), Uniwersytetem Karola w Pradze (Czechy), University of Lahti (Finlandia), University of Nigeria (Nigeria), University of Saragossa (Hiszpania), University of Viseau (Portugalia), Holar University College (Islandia) oraz Royal Technical University KTH w Sztokholmie (Szwecja). Współautor projektów architektonicznych i urbanistycznych (zrealizowanych w Libii, Nigerii, Niemczech oraz w Polsce). Członek Stowarzyszenia Architektów Polskich SARP, Polskiego Towarzystwa Nauk Społecznych o Sporcie PTNSS oraz naukowych towarzystw międzynarodowych (EURA, IAPS, ISSSS, RSA). Odznaczona Medalem Komisji Edukacji Narodowej za zasługi dydaktyczne i naukowe (2019).

Kontakt: Katedra Turystyki i Rekreacji, WWF AWF Warszawa

e-mail: anna.piechotka@gmail.com

ORCID 0000-0003-0429-0327

Anna Pawlikowska-Piechotka, prof. dr hab. inż. arch. (DArch, DEng, Professor) - graduate of the Faculty of Architecture at Warsaw University of Technology. For many years associated with the Faculty of Tourism and Recreation at the Józef Piłsudski University of Physical Education in Warsaw and the Faculty of Architecture at the Warsaw University of Technology. She specializes in research on the sustainable development of sports, recreation and tourism spaces. Participated in several multicenter, international research projects domestically and abroad. Author of over two hundred scientific articles, books, scripts and several dozen of expert opinions; co-author of planning studies (architecture, urban planning) and several patent applications (equipment for the disabled). Actively participated and presented papers at dozens of conferences organized by foreign academic centres and at several UN conferences (UN Habitat II, UN WTO). Lecturer and participant of scientific exchange with: University College of Birmingham (United Kingdom), University of Evora (Portugal), Charles University of Prague (Czech Republic), University of Lahti (Finland), University of Nigeria (Nigeria), University ofSaragossa (Spain), University ofViseu (Portugal), HolarUniversity College (Iceland) and KTHRoyal InstituteofTechnologyin Stockholm (Sweden). Co-author of architectural and urban development projects (implemented in Libya, Nigeria, Germany and Poland). Member of the Association of Polish Architects (SARP), the Polish Society for Social Sciences in Sport (PTNSS) and scientific international societies (EURA, IAPS, ISSSS, RSA). Awarded the Medal of the Commission of National Education for her teaching and scientific merits (2019). Contact: Faculty of Tourism and Recreation, Józef Piłsudski University of Physical Education in Warsaw e-mail:anna.piechotka@gmail.com

ORCID: 0000000304290327 
